\title{
Analisis SWOT (strengths, weaknesses, opportunities, threats) pusat informasi dan konseling remaja (pik-remaja)
}

\author{
Nurochim Nurochim ${ }^{*}$ \\ UIN Syarif Hidayatullah Jakarta, Indonesia
}

\section{Article Info \\ Article history: \\ Received Des $02^{\text {nd }}, 2020$ \\ Revised Jan $03^{\text {rd }}, 2021$ \\ Accepted Feb 20 $0^{\text {th }}, 2021$}

\section{Keyword:}

Analisis SWOT

Konseling remaja

PIK-Remaja

\begin{abstract}
This study aims to describe an analysis of the strengths, weaknesses, opportunities and threats of the Youth Information and Counseling Center program (PIK-Remaja). This study uses a literature review method, in the form of scientific reports published in reputable national and international journals. The strength of the PIK-Remaja program is that it is a program designed with peer counseling as and integrated with social and religious institutions. The weakness of this program is the ineffective and inefficient socialization, as well as the commitment of all stakeholders in supporting the program. Opportunities for this program are policies that support coordination between central and regional governments for guidance and funding. The challenge for the PIK-Remaja program is the demographic conditions of the population and adolescents who are surrounded by globalization and technological developments.
\end{abstract}

(C) 2021 The Authors. Published by Indonesian Institute for Counseling,

Education and Therapy (IICET). This is an open access article under the CC BY license (https://creativecommons.org/licenses/by/4.0/)

\section{Corresponding Author:}

Nurochim

UIN Syarif Hidayatullah Jakarta

Email: nurochim@uinjkt.ac.id

\section{Pendahuluan}

Anak usia remaja merupakan kelompok potensial. Kelompok ini sebagai kelompok yang rata-rata memiliki kesehatan yang baik, selain itu anak usia in adalah anak yang sedang menempuh pendidikan. Anak usia remaja memiliki berbagai kecerdasan yang dapat dikembangkan yakni kecerdasaan kinestetik, seni, matematika, interpersonal dan intrapersonal. Berbagai kecerdasaan tersebut jika dikembangkan dengan baik maka akan mendorong terwujudkan sumber daya yang berkualitas dan berdampak pada kualitas bangsa. Pada anak usia remaja inilah bakat dapat dikembangkan secara lebih optimal.

Populasi remaja di Indonesia yang didefinisikan berusia 16-30 tahun berdasarkan undang-undang nomor 40 tahun 2009, hasil susenas tahun 2019 pemoda sekitar seperempat dari total penduduk (Badan Pusat Statistik, 2019, Statistik Pemuda), yang paling banyak berada di Pulau Jawa. Berdasarkan susenas 2019, remaja di Indonesia sudah bisa membaca dan menulis yang rata-rata lulus Sekolah Menengah Pertama. Selain itu sebagian besar pemuda memiliki ponsel dan menggunakan komputer serta internet.

Permasalahan remaja di Indonesia mulai dari keluhan kesehatan fisik dan mental, kesulitan belajar, perundungan, hingga penerimaan terhadap dirinya yang kurang. Selain itu remaja membutuhkan teman sebaya, namun teman sebaya berpotensi menyebabkan tekanan untuk berbuat keonaran dan perilaku menyimpang lainnya (Diananda, 2019). Pada anak usia remaja ini sangat penting adanya bimbingan pendidikan dan karir, sehingga para remaja dapat mengembangkan bakat dan minatnya pada lokasi pendidikan dan pasar tenaga kerja yang sesuai. Selain itu angka pernikahan dini pada remaja di Indonesia masih tinggi (Badan Pusat Statistik, 2020).

Di lingkup persekolahan, terdapat program bimbingan dan konseling sebagai upaya pendampingan anak sekolah. Upaya pendampingan ini dirancang sebagai program yang efektif dan efisien yang dilayani oleh konselor sekolah. Konseling sekolah mencakup layanan kebutuhan siswa yang berfokus pada akademik, 
karir, dan domain personal dan sosial (Kimbel \& Clemens, 2014). Konseling di sekolah lekat dengan dampak positif yang diharapkan seperti meningkatkan disiplin dan prestasi siswa. Konseling di sekolah diharapkan dapat membentuk paradigma multikultur baik secara sikap dan keyakinan/kepercayaan, pengetahuan, dan keterampilan (Hastuti \& Marheni, 2017). Paradigma multikultur tersebut juga bertujuan untuk mencapai hasil konseling dan komunikasi antara konselor dan konseli secara efektif dan efisien. Hal tersebut sesuai dengan standar nasional konseling, dimana konselor memberikan pelayanan dengan empati, menghormati keragaman, berfokus pada konseli, dan menganalisis dampak layanan (Kementerian Pendidikan Nasional Republik Indonesia, 2008, Standar Kualifikasi Akademik dan Kompetensi Konselor). Konseling di sekolah sebagai program layanan kesiswaan dirancang dan dipersiapkan secara kebijakan makro (kebijakan nasional) dan mikro (kebijakan sekolah sebagai wujud otonomi daerah). Program konseling di sekolah sebagai upaya mewujudkan manusia yang cakap dan sehat, sehingga menjadi bagian yang tidak terpisah dengan sistem persekolahan.

Namun demikian program bimbingan dan konseling di sekolah menemui beberapa kendala yang menyebabkan konseling di sekolah belum terlaksana dengan baik. Kendala tersebut adalah salah satunya guru bimbingan dan konseling masih sebagai guru honor (wawancara penulis dengan guru bimbingan konseling pada 4 Oktober 2020), hal tersebut menyebabkan guru mengalami kesenjangan pendapatan. Selain itu sarana dan prasarana serta waktu untuk konseling kurang memadai, ditambah dengan guru bimbingan dan konseling harus melaksanakan sosialisasi tentang bimbingan dan konseling serja menjalin kerjasama dengan seluruh warga sekolah (Permana, Syahniar, \& Daharnis, 2014). Program bimbingan dan konseling belum dimanfaatkan secara optimal khususnya para siswa, sebab masih ada anggapan bahwa ketika berhadapan dengan guru BK, terstigma sebagai siswa yang bermasalah (Kulsum, 2013). Guru bimbingan konseling yang masih dianggap belum memiliki kepedulian penuh, empati, dan kesegeraan (Khomsiyati, 2015) hal tersebut menyebabkan siswa enggan memanfaatkan program bimbingan konseling di sekolah. Oleh sebab itu penting dilaksanakan program bimbingan konseling yang menyasar remaja yang tidak hanya berbasis pada sekolah, namun juga berbasis masyarakat.

PIK-Remaja merupakan salah satu program pelayanan informasi dan konseling tentang pendewasaan usia perkawinan, fungsi keluarga, informasi dan konseling seksualitas, HIV AIDS, dan obat terlarang, keterampilan hidup, dan pembentukan generasi berencana (Forum PIK Remaja formasi Kab. Bandung Barat, 2020, Tentang PIK Remaja). PIK-Remaja tersebut tidak terbatas wilayah administrasi, namun melayani seluruh remaja darimana berasal, artinya melayani remaja yang berasal dari luar wilayah administrasi (Bkkbn Kampung KB, 2020, Pembinaan PIK Remaja). PIK-Remaja ini untuk penyebutannya biasa dikaitkan dengan tempat dan lembaga pembinanya seperti PIK-Remaja Sekolah, PIK-Remaja Masjid, PIK-Remaja Pesantren. Pengelola PIK-R tersebut adalah remaja yang memiliki komitmen mengelola dan telah mengikuti pelatihan menggunakan modul dan kurikulum yang disusun oleh BKKBN (BKKBN, 2012). Tingkat pelaksananaan PIK-Remaja pada saat ini belum terlaksana secara optimal, informasi mengenai PIKR belum merata di seluruh wilayah di Indonesia (Rini \& Tjadikijanto, 2019). Belum semua wilayah hingga tingkat kecamatan belum memiliki kader dan konselor terlatih (Bkkbn laporan PIK-KRR, 2020). Oleh sebab itu penting adanya kajian analisis SWOT program PIK-Remaja. Analisis SWOT penting untuk menyusun strategi optimalisasi program PIK-Remaja.

\section{Metode}

Metode yang digunakan dalam penelitian ini adalah kajian literatur. Literatur yang dikaji berupa naskah ilmiah yang diterbitkan di jurnal nasional dan internasional, yang membahas tentang kekuatan, kelemahan, peluang, dan ancaman program konseling remaja. Selain itu literatur yang dikaji adalah laporan tentang best practice PIK-R. Kajian literatur ini diupayakan dapat menggambarkan kekuatan, kelemahan, peluang, dan tantangan program PIK-R.

\section{Hasil dan Pembahasan}

\section{Analisis SWOT}

Analisis SWOT sebagai alat penting untuk perencanaan strategis, memebantu organisasi untuk mencapai tujuan dengan cara dengan menganalisis lingkungan internal dan eksternal. Analisis ini memastikan kapasistas organisasi didayagunakan dengan optimal dan bernilai bagi konsumen, dengan membagi faktor menjadi empat ranah (Phadermrod, Crowder, \& Wills, 2019). Manajemen strategis dipahami sebagai pengambilan keputusan dan mengambil tindakan oleh pemangku kebijakan. Analisis SWOT sebagai starategi untuk menyusun kajian stratagis sebuah organisasi atau program, sehingga dapat meningkatkan 
hasil dan dampak yang akan dicapai (Ahmed, Ahmed, Shimul, \& Zuñiga, 2015; Davies, 1998; Gurel \& TAT, 2017). Strength sebagai aspek yang kuat yang mendukung program atau organiasi diartikan dengan kekuatan. Weaknesses sebagai aspek kelemahan dari sebuah institusi atau program yang didefinisikan dengan kelamahan. Opportunities adalah aspek yang menggambarkan kondisi di luar organisasi atau program berpeluang untuk berhasil atau terlaksana. Sedangkan threats menunjukkna kondisi di luar organisasi atau program yang menghambat atau membahayakan organiasi atau sebuah program (Polat, Çelik, \& Okçu, 2019). Analisis ini digunakan untuk menganalisis program PIK-R, sehingga program tersebut dapat terlaksana dengan optimal.

\section{Strength (Kekuatan)}

Sudah ada pedoman mengenai pengelolaan PIK-Remaja dan Mahasiswa yang disusun oleh BKKBN. Pedoman tersebut disusun secara runtut dari pemahaman tentang PIK- Remaja, dilanjutkan dengan pembahasan tentang kebijakan dan strategi serta kegiatan penglolaan PIK-Remaja, mekanisme pengelolaan PIK-Remaja dibahas pada bab 3 pedoman ini (BKKBN, 2012). Pedoman tersebut berdasarkan pertimbangan adanya kesadaran akan upaya peningkatan kualitas remaja di Indonesia. Kesadaran pemangku kebijakan sebagai salah satu kekuatan program PIK-Remaja, oleh karena kesadaran tersebut diharapkan pemangku kebijakan dapat mendukung PIK-R.

PIK-Remaja ini dari, oleh, dan untuk remaja, hal ini menjadi peluang. Hal tersebut sesuai dengan penelitian Fadzilla dan Djannah bahwa pemanfaatan PIK-R dipengaruhi oleh peran konselor sebaya (Fadzilla \& Djannah, 2018). Sebab didalamnya terdapat konselor dan konseling sebaya yang memungkinkan remaja untuk terbuka memperoleh dan menyampaikan informasi terkait keluarga berrencana dan keterampilan hidup. Komunikasi antar sebaya dianggap sebagai komunikasi yang efektif dalam komunikasi perubahan perilaku (Smith \& Petosa, 2016). Sebagaimana penelitian Smith dan Petosa tersebut, konseling sebaya sebagai alternatif solusi untuk mempromosikan perilaku dan dampak pendidikan kesehatan mental.

PIK-Remaja ini terintegrasi dengan lembaga sekolah, pesantren, karang taruna, remaja masjid, gereja, dan vihara. Upaya integrasi tersebut menyasar lembaga penting dan formal dalam masyarakat. Selain itu lembaga keagamaan juga menjadi kekuatan, sebab pesan berbasis keyakinan keagamaan biasanya lebih mengena. Upaya layanan konseling integratif tersebut sebagai upaya holistik yang berpusat pada klien (Halsall et al., 2019). Layanan konseling remaja yang terintegrasi dengan masyarakat sebagai layanan komprehensif dengan bahasa umum yang dapat dipahami (Settipani et al., 2019), sehingga layanan ini dapat terlaksana dengan efektif dan efisien.

Kegiatan yang dilaksanakan pada program PIK-R adalah dialog interaktif, konseling, menarik minat remaja dengan menyusun kegiatan konsultasi kecantikan, gizi, olahraga, dan kesenian. Selain itu pelaksanaan kegiatan sosial berwawasan kependudukan. Materi konseling sebaya pada program PIKRemaja adalah fungsi keluarga, pendewasaan usia perkawinan, resiko perilaku remaja, keterampilan hidup. Materi-materi tersebut sangat penting bagi remaja dan sebagai bekal untuk mewujudkan keluarga yang sejahtera.

Program PIK-Remaja memiliki basis data terpadu, yang mencakup indetifikasi jumlah organisasi PIK-r di setiap daerah, jumlah kader, dimulai dari tingkat nasional hingga ke kecamatan. Hal tersebut menjadi kekuatan untuk memetakan kondisi nyata pelaksanaan PIK-Remaja secara kuantitatif, yang menuntun pada kajian mendalam selanjutnya.

\section{Weakness (Kelemahan)}

Tantangan pelaksanaan program PIK-R ini salah satunya adalah kurangnya komitmen dari lembaga yang diharapkan melaksanakan pembinaan program ini, mulai dari lingkup persekolahan, lembaga karang taruna, rukun tetangga, rukun warga, sampai tingkat kementerian pusat yang belum memiliki jumlah dan mutu sumber daya manusa yang memadai. Pencatatan dan pelaporan program ini belum ada petunjuk teknis (Ibaadillah \& Samtyaningsih, 2017), sehingga kegiatan laporan dan monitoring terkesan kurang tertib. Sulitnya pengurus PIK-Remaja dalam membagi waktu dalam melaksanakan konseling dan kegiatannya sendiri, selain itu kurangnya monitoring dan evaluasi menjadi hambatan program (Husanah \& Fenny Sitti Rubiah Harahap, 2019). Sosialisasi program belum terlaksana dengan berkelanjutan dan berkesinambungan, serta analisis peluang untuk pengembangan upaya integrasi dengan program lain. Upaya integrasi untuk meningkatkan kerangka pikir optimalisasi program. Selain itu upaya integrasi juga penting dianalisis terkait program penelitian dan pengembangan, sehingga ditemukan pola atau faktor yang mendukung dan menghambat program. 


\section{Opportunities (Peluang)}

Undang-undang nomor 33 tahun 2004 tentang perimbangan keuangan antara pemerintah pusat dan daerah. Undang-undang ini sebagai acuan pelayanan umum dan relasi pendanaan berdasarkan kewenangan dan tanggung jawab (Undang-Undang Republik Indonesia Nomor 33 Tahun 2004, 2004). Program PIK-R sebagai salah satu layanan umum dinaungi oleh undang-undang ini, sehingga pelaksanaannya sebagai tanggung jawab bersama pemerintah pusat dan daerah.

Peraturan pemerintah nomor 38 tahun 2007 tentang pembagian urusan pemerintah pusat dan daerah. Berdasarkan peraturan pemerintah tersebut, PIK-R sebagai bagian dari program keluarga berencana dan keluarga sejahtera sebagai urusan pemerintahan. Dan urusan pemerintahan tersebut dilimpahkan pada pemerintah daerah bersama dengan sumber pendanaan, sarana dan prasarana, dan sumber daya manusia (Peraturan Pemerintah Republik Indonesia Nomor 38 Tahun 2007, 2007).

PIK-Remaja sebagai bagian program keluarga berencana dipayungi juga oleh standar pelayanan minimal bidang keluarga berencana yang berdasarkan pada hak asasi manusia (Riyanti, Widanti, \& Lucyati, 2016). Standar pelayanan minimal tersebut sebagai dasar pelaksanaan komunikasi dan edukasi untuk membentuk keluarga sejahtera. Selain itu PIK-Remaja dapat diintegrasikan dengan program konseling sekolah, untuk mengantisipasi faktor negatif yang dapat mempengaruhi prestasi akademik. Program konseling di sekolah terlaksana dengan efektif, jika dikaitkan dengan program sejenis secara berkelanjutan. Program PIK-R sebagai saluran informasi kesehatan reproduksi remaja yang inklusif. Program tersebut dapat menjangkau dan mememuhi hak kesehatan reproduksi dan seksualitas para remaja bangsa, sebagai ejawantah kesepakatan pertemuan di Kairo pada tahun 1994 (Sekarpuri, 2014).

\section{Threats (Tantangan)}

Perkembangan penduduk di Indonesia sebagai Negara dengan penduduk nomor 4 (empat) di dunia (Indonesia-investments, 2017). Dengan kondisi kepadatan penduduk tersebut, ditambah dengan berbagai kondisi demografi dan ekonomi, maka program PIK-R diharapkan mampu menyediakan sumber daya manusia yang dilatih secara berkelanjutan sesuai dengan modul yang dikembangkan oleh BKKBN, namun juga mempertimbangkan aspek sosial budaya atau demografi penduduk Indonesia.

Jumlah penduduk usia remaja di Indonesia yang pada saat ini berada di era digital memiliki pemikiran dan sudut pandang yang bervariasi. Kerangka pikir bahwa dengan kegiatan konseling membuang waktu dengan percuma, maka lebih baik melakukan kegiatan yang sesuai dengan hobi atau kegiatan yang berdampak ekonomi. Oleh sebab itu program PIK-R sangat penting memahami karakteristik kerangka pikir usia remaja secara detail. Ditambah dengan luasnya wilayah geografis Indonesia, dengan kondisi sarana dan prasarana yang masih timpang. Kondisi perbedaan kerangka pikir tentang prioritas optimalisasi program para pemangku kebijakan di setiap level pemerintahan.

Remaja dan globalisasi yang ditandai juga dengan perkembangan teknologi menjadi tantangan PIK-R. Pada era ini remaja mengalami konflik intrapersonal, remaja berkehendak untuk berperilaku sesua aturan masyarakat, namun juga ingin meniru berbagai model dan perilaku serta gaya yang muncul atau sedang trend (Krisnaningrum, Masrukhi, \& Atmaja, 2017). Selain itu budaya mendengarkan nasehat mulai ditinggalkan karena dipengaruhi oleh globalisasi (Syam, 2015). Globalisasi yang mempengaruhi perilaku remaja menjadi salah satu tantangan dan hambatan program PIK-R.

Pada kondisi pandemic covid-19, tantangan program PIK-R lebih berat. Sebab duta generasi berencana harus berinovasi dalam memberikan akses informasi dan konseling secara mental dan fisik, tanpa bertatap muka. Para duta diharapkan menjadi teladan di masa yang sulit, untuk tetap berperilaku positif. Ditambah dengan masih tingginya pernikahan dini (DP3KB Brebes, 2020).

\section{Simpulan}

Program PIK-Remaja selaku program BKKBN yang menyasar anak usia remaja sebagai upaya meningkatkan kesehatan mental dan fisik, demi suksesnya pembangunan nasional dan pembangunan berkelanjutan. Analisis SWOT PIK-R menunjukkan bahwa kekuatan yang dimiliki program tersebut dari sisi sumber daya manusia, upaya integtatif dengan masyarakat, jenis layananya. Namun demikian kelemahan program tersebut adalah kurangnya sosalisasi yang masif, dan komitmen pemangku kebijakan untuk keterlaksanaan program. Peluang PIK-R adalah berbagai kebijakan yang mendukung seperti undang-undang dan peraturan pemerintah sehingga memungkinkan adanya koordinasi dari sisi pembinaan dan pembiayaan. Namun demikian tantangan PIK-R yang muncul adalahh kondisi demografis penduduk dan remaja, dan 
dampak globalisasi dan perkembangan teknologi. Dengan analisis SWOT tersebut diharapkan adanya kajian strategis lebih lanjut untuk menyusun rancangan strategis program PIK-Remaja.

\section{Referensi}

$\begin{array}{lllll}\text { PIK-KRR. } & \text { (n.d.). } & \text { Retrieved } & \text { January } & \text { 1, }\end{array}$ http://aplikasi.bkkbn.go.id/pikrm/Report/LaporanPIKRM.aspx

Ahmed, J. U., Ahmed, K. U., Shimul, M. A. S., \& Zuñiga, R. (2015). Managing Strategies for Higher Education Institutions in the UK. Higher Education for the Future, 2(1), 32-48. https://doi.org/10.1177/2347631114558189

Badan Pusat Statistik. (2019). Statistik Pemuda Indonesia 2019. Retrieved from http://library1.nida.ac.th/termpaper6/sd/2554/19755.pdf

Badan Pusat Statistik. (2020). Pencegahan Perkawinan Anak percepatan yang tidak bisa ditunda. Badan Pusat Statistik, 0-44.

BKKBN. (2012). Pedoman Pengelolaan Pusat Informasi dan Konseling Remaja Dan Mahasiswa (PIK R/M). In Badan Kependudukan Dan Keluarga Berencana Nasional Direktorat Bina Ketahanan Remaja. Jakarta: Badan Kependudukan Dan Keluarga Berencana Nasional Direktorat Bina Ketahanan Remaja.

Bkkbn Kampung KB. (2020). Pembinaan PIK Remaja. Retrieved December 30, 2020, from bkkbn website: https://kampungkb.bkkbn.go.id/postSlider/1381/176984\#: :text=Pusat Informasi dan Konseling Remaja,serta kegiatan-kegiatan penunjang lainnya.

Davies, B. (1998). Strategic planning in schools: An oxymoron? School Leadership and Management, 18(4), 461-473. https://doi.org/10.1080/13632439869439

Diananda, A. (2019). Psikologi Remaja Dan Permasalahannya. Journal ISTIGHNA, 1(1), 116-133. https://doi.org/10.33853/istighna.v1i1.20

DP3KB Brebes. (2020). Pembinaan Kelompok PIK Remaja. Retrieved February 3, 2021, from http://dp3kb.brebeskab.go.id/pembinaan-kelompok-pik-remaja/

Fadzilla, V., \& Djannah, S. N. (2018). Faktor - Faktor Yang Berhubungan Dengan Pemanfaatan Pusat Informasi Dan Konseling Remaja (Pik-R) Pada Remaja Di SMA N 1 Sanden. Jurnal Cakrawala Promkes, 1(1), 9-16. https://doi.org/10.12928/promkes.v1i1.291

Forum PIK Remaja formasi Kab. Bandung Barat. (2020). Tentang PIK Remaja. Retrieved December 30, 2020, from Artikel Web website: https://pikremaja.or.id/tentang-pik-remaja/

Gurel, E., \& TAT, M. (2017). SWOT Analysis: A Theoretical Review. The Journal of International Social Research, 10(51), 995-1006.

Halsall, T., Manion, I., Iyer, S. N., Mathias, S., Purcell, R., \& Henderson, J. (2019). Trends in Mental Health System Transformation: Integrating Youth Services within the Canadian Context. Healthcare Management Forum, 32(2), 51-55. https://doi.org/10.1177/0840470418808815

Hastuti, M. M. S., \& Marheni, A. K. I. (2017). Kompetensi Konseling Multikultur Bagi Konselor Sekolah: Suatu Kajian Teoretis. Proceeding Seminar Dan Lokakarya Nasional Bimbingan Dan Konseling 2017, 1(mcc), 93-109.

Husanah, E., \& Fenny Sitti Rubiah Harahap. (2019). Pelaksanaan PIK-Remaja Di SMA/SMK Se Kota Pekanbaru. Menara Ilmu, XIII(2), 102-114. Retrieved from http://jurnal.umsb.ac.id/index.php/menarailmu/article/view/1189

Ibaadillah, A. A., \& Samtyaningsih, D. (2017). Evaluasi Pelaksanaan PIK-R di Kabupaten Banyuwangi. Prosiding Seminar Nasional "Pengembangan Sumber Daya Perdesaan Dan Kearifan Lokal Berkelanjutan", 17 18(November), 480-488.

Indonesia-investments. (2017). Penduduk Indonesia dan Potensi Ekonomi. Retrieved December 31, 2020, from Https://Www.Indonesia-Investments.Com website: https://www.indonesiainvestments.com/id/budaya/penduduk/item67?

Kementerian Pendidikan Nasional Republik Indonesia. Peraturan Menteri Pendidikan Nasional Republik Indonesia Nomor 27 Tahun 2008 Tentang Standar Kualifikasi Akademik dan Kompetensi Konselor. , (2008).

Khomsiyati, S. (2015). Hubungan Kemampuan Guru Bimbingan dan Konseling Membina Hubungan Konseling dengan Motivasi Siswa Melanjutkan Konseling. Jurnal Konseling Dan Pendidikan, 2(1), 52-59. Retrieved from http://jurnal.konselingindonesia.com/index.php/jkp/article/view/165/142

Kimbel, T., \& Clemens, E. V. (2014). The Development and Validation of the School Counseling Program Report Card - Student Version. Professional School Counseling, 18(1), 111-124. https://doi.org/10.1177/2156759x0001800111

Krisnaningrum, I., Masrukhi, \& Atmaja, H. T. (2017). Perilaku Sosial Remaja Era Globalisasi di SMK Muhammadiyah Kramat, Kabupaten Tegal. Journal of Educational Social Studies, 6(9), 92-98. 
Kulsum, S. (2013). Peranan Bimbingan dan Konseling dalam Domain Pengembangan Diri Siswa. Jurnal Konseling Dan Pendidikan, 1(1), 67-72. https://doi.org/10.29210/11200

Peraturan Pemerintah Republik Indonesia Nomor 38 Tahun 2007. Peraturan Pemerintah Republik Indonesia Nomor 38 Tahun 2007 Tentang Pembagian Urusan Pemerintahan Antara Pemerintah, Pemerintah Daerah, Pemerintah Daerah Provinsi, dan Pemerinatah Daerah Kabupaten/Kota. , (2007).

Permana, S. A., Syahniar, S., \& Daharnis, D. (2014). Pelaksanaan Layanan Bimbingan dan Konseling di Sekolah Menengah Atas Negeri (SMAN) 4 Kerinci. Konselor, 3(4), 168-179.

Phadermrod, B., Crowder, R. M., \& Wills, G. B. (2019). Importance-Performance Analysis Based SWOT analysis. International Journal of Information Management, 44, 194-203. https://doi.org/10.1016/j.ijinfomgt.2016.03.009

Polat, S., Çelik, Ç., \& Okçu, Y. (2019). School Administrators' Perspectives on Teachers From Different Generations: SWOT Analysis. SAGE Open, 9(3), 1-12. https://doi.org/10.1177/2158244019861499

Rini, I. M., \& Tjadikijanto, Y. D. (2019). Gambaran Program Generasi Berencana (GenRe) di Indonesia dan di Provinsi Jawa Timur Tahun 2017. Jurnal Biometrika Dan Kependudukan, 7(2), 168. https://doi.org/10.20473/jbk.v7i2.2018.168-177

Riyanti, Widanti, A., \& Lucyati, A. (2016). Ketentuan Tentang Standar Pelayanan Minimal Bidang Keluarga Berencana Dan Keluarga Sejahtera Berdasarkan Asas Perikemanusiaan Dan Hak Asasi Manusia. Soepra Jurnal Hukum Kesehatan, 2(2), 204-216. https://doi.org/10.24167/shk.v2i2.823

Sekarpuri, A. D. (2014). Inklusi Saluran Informasi Kesehatan Reproduksi Remaja (Vol. 3).

Settipani, C. A., Hawke, L. D., Cleverley, K., Chaim, G., Cheung, A., Mehra, K., ... Henderson, J. (2019). Key Attributes of Integrated Community-based Youth Service Hubs for Mental Health: A Scoping Review. International Journal of Mental Health Systems, 13(1), 1-26. https://doi.org/10.1186/s13033-0190306-7

Smith, L. H., \& Petosa, R. L. (2016). A Structured Peer-Mentoring Method for Physical Activity Behavior Change Among Adolescents. Journal of School Nursing, 32(5), 1-9. https://doi.org/10.1177/1059840516644955

Syam, H. M. (2015). Globalisasi Media Dan Penyerapan Budaya Asing, Analisis Pada Pengaruh Budaya Populer Korea Di Kalangan Remaja Kota Banda Aceh. Avant Garde Jurnal Ilmu Komunikasi, 3(1), 5470.

Undang-Undang Republik Indonesia Nomor 33 Tahun 2004. Undang-Undang Republik Indonesia Nomor 33 Tahun 2004 Tentang Perimbangan Keuangan Antara Pemerintah Pusat dan Pemerintah Daerah. , (2004). 